\title{
Evaluation In Vitro of Frictional Resistance of Self- Ligating Esthetic and Conventional Brackets
}

\author{
Evaluación In Vitro de la Resistencia Friccional en \\ Brackets de Autoligado Estéticos y Convencionales
}

Maria Rita Danelon do Amaral"; Perrim Smith Neto"; Matheus Melo Pithon ${ }^{*+*+*}$ \& Dauro Douglas Oliveira*

AMARAL, M. R. D.; NETO, P. S.; PITHON, M. M. \& OLIVEIRA, D. D. Evaluation in vitro of frictional resistance of selfligating esthetic and conventional brackets. Int. J. Odontostomat., 8(2):261-266, 2014.

ABSTRACT: The objective of this study was to evaluate the frictional resistance created in self-ligating esthetic and conventional brackets during simulated orthodontic sliding mechanics. Four different types of brackets were used: 3 selfligating type of different brands (Clarity ${ }^{\mathrm{TM}} \mathrm{SL}, 3 \mathrm{M}$ Unitek; Damon $3 \circledR$, Ormco Corporation; In-Ovation C $\AA$, GAC International), in addition to conventional esthetic brackets (Radiance $\AA$, American Orthodontics) associated with conventional elastic ligatures (Sani-tie $\AA_{,}$GAC International) and low friction ligatures (Slide ${ }^{\circledR}$, Leone). To simulate sliding mechanics, stainless steel wires with thicknesses of 0.018 " and 0.017"x0.025" (GAC International) were used. Five groups (n=10) were submitted to five consecutive mechanical tests in a universal test machine model Emic $®$ DL 500 . The results showed low frictional levels in all tested self-ligating brackets and with use of 0.018 " wire $(p<0.05)$. However, with $0.017 \times 0.025$ " wire, Groups Damon 3 , Clarity SL and Slide showed lower frictional forces when compared with In-Ovation C ( $p>0.05)$. Moreover, conventional esthetic brackets associated with conventional ligatures resulted in greater frictional resistance with both wires tested ( $p>0.05)$. All the self-ligating brackets presented lower frictional levels than the conventional accessories. Active self-ligating bracket InOvation $\mathrm{C}$, demonstrated higher degree of frictional force when associated with rectangular wire. The Slide $₫$ ligature may be an alternative to the use of self-ligating brackets.

KEY WORDS: Friction, tensile strength, orthodontic brackets.

\section{INTRODUCTION}

When sliding mechanics are used in Orthodontics, the frictional resistance generated at the bracket/orthodontic wire interface may influence the efficiency of the mechanics, resulting in a lower velocity of tooth movement (Yeh et al., 2007; Fidalgo et al., 2011). Friction may be defined as a force that is opposed to or retards the movement of a body in relation to the surface of the other (Ribeiro et al., 2012; Thorstenson \& Kusy, 2002).

As sliding mechanics are more frequently used in orthodontics, control of friction has become one of the main concerns related to the success of this type of treatment (Regis et al., 2011; Kao et al., 2011; Tecco et al., 2011). Among the various attempts to reduce friction during orthodontic treatment, there is the selfligating bracket system. This type of bracket requires no ligatures, as the wire is retained in the channel by means of a mechanical system constructed at the vestibular face of this accessory, and which functions as a fourth wall, making this bracket similar to a tube (Fry, 2011; Huang et al., 2011; Pliska et al., 2011; Kaklamanos et al., 2011). Although it is not a new idea, as it was first tested in 1935, it is only over the last few years that these accessories have begun to account for a significant percentage of the market sales. From then on, self-ligating brackets have been improved with variations in shape, size, mechanics and materials (Fernandes, 2012; Harradine, 2001; Rinchuse \& Miles, 2007).

\footnotetext{
Former orthodontic residents. Pontifical Catholic University of Minas Gerais, Belo Horizonte, Brazil.

** Professor of Mechanical Engineering, Pontifical Catholic University of Minas, Belo Horizonte, Brazil.

.** Professor of Orthodontics, Southwest Bahia State University (UESB), Jequié, Brazil.

${ }^{* * * * *}$ Program Director of Orthodontics, Pontifical Catholic University of Minas Gerais, Belo Horizonte, Brazil.
} 
The high demand for orthodontic treatment by adult patients has resulted in the need for a more esthetic appearance of the appliances used. This has led to the beginning of self-ligating accessories being made of polycarbonate and ceramics (Bazakidou et al., 1997; Hain et al., 2003; Shivapuja \& Berger, 1994). There are persistent doubts about whether these brackets maintain or do not maintain, the characteristics of low frictional levels presented by the metal selfligating types.

Based on this premise, the authors' proposal in the present study was to evaluate in vitro the frictional resistance force of different esthetic self-ligating brackets and a conventional esthetic bracket associated with an elastic ligature with a low frictional level and conventional elastic ligatures.

\section{MATERIAL AND METHOD}

Three types of esthetic self-ligating brackets were tested: Clarity ${ }^{\mathrm{TM}} \mathrm{SL}$ (3M Unitek, Monrovia, California, USA), with stainless steel channel and passive channel closing system; Damon $3 \AA$ (Ormco Corporation, Glendora, California, USA), with stainless steel channel and passive channel closing system; InOvation C® (GAC International, Bohemia, New York, USA), with ceramic channel and active channel closing system (Table I and Fig. 1).

As control the conventional esthetic brackets Radiance ${ }^{\circledR}$ (American Orthodontics, Sheboygan, Wisconsin, USA), associated with conventional elastic ligatures (GAC International, Bohemia, New York, USA) and low friction Slide ${ }^{\circledR}$ (Leone, Florence, Italy) were used.

A total of 100 brackets were used, forming 10 groups $(n=10)$ : All the brackets used were for the maxillary right central incisor with channel 0.022 " $x$ 0.028 ", prescription Roth and MBT (angulations of 5 ? and 12 ? torque).

To perform the tests, stainless steel orthodontic wires in rod form were used, with caliber 0.018" (GAC International, Bohemia, New York, USA) and 0.017" $x$ 0.025" (GAC International, Bohemia, New York, USA).

Each test specimen, formed of bracket/wire or bracket/wire/ligature was submitted to 5 consecutive tests, with a total of 50 tests in each group. To evaluate the frictional force, the combinations of brackets, wires and types of ligatures were submitted to mechanical tests in a Universal Test machine Emic $®$ DL 500 (São José dos Pinhais, Paraná, Brazil). A $5 \mathrm{~N}$ load cell was used and the tests were performed at a speed of 1 $\mathrm{mm} / \mathrm{min}$.

With the purpose of simulating orthodontic sliding mechanics, the machine was adjusted by fabricating a device composed of two aluminum plates $30 \mathrm{~mm}$ wide, $10 \mathrm{~mm}$ thick and $60 \mathrm{~mm}$ high. One of these plates was fixed to the bottom part of the universal test machine by means of a device made of polypropylene that allowed the bottom plate to be adjusted in the antero-posterior direction, which enabled passive alignment of the wire in the channel of the bracket. The other aluminum plate was fixed directly to the load cell on the top part of the machine, which would undergo displacement while the tests were being performed. Parallelism between the top and bottom plate was guaranteed with the use of a comparator clock with a resolution in hundredths (Mitutoyo, Santo Amaro, São Paulo, Brazil). Therefore, the tensile test in static straight line was used, with the bracket remaining at rest in relation to its base and the wire sliding along the channel.

Each orthodontic wire segment used was $3 \mathrm{~cm}$ long. At the top extremity of each of the wires a hook was made, with a standardized shape, to fit into the top aluminum plate. After the hook was made, the wire segment was evaluated by means of a profile projector, with the purpose of standardizing the bends and precise determination of the long axis of the wire segment.

In the esthetic self-ligating brackets, the wire was placed parallel to the aluminum base and the bracket closing cover was locked with the aid of a Hollemback?/Hollenbeck type instrument (Jon, São Paulo, Brazil), in the case of the Damon $3 \circledR$ (Ormco Corporation, Glendora, California, USA) and In-Ovation C ${ }^{8}$ (GAC International, Bohemia, New York, USA) brackets. In the Clarity ${ }^{\mathrm{TM}} \mathrm{SL}$ Group (3M Unitek, Monrovia, California, USA) the wire was inserted under manual pressure. In the groups with conventional esthetic brackets, the ligatures were tied by means of the instrument used for the insertion of elastic ligatures Straight-Shooter ${ }^{\circledR}$ (TP Orthodontics, La Porte, Indiana, USA), to standardize the amount of extension of the elastic ligature at the time it was inserted. The Slide ${ }^{\circledR}$ elastics were inserted in accordance with the manufacturer's instructions (Fig. 2). 
Table I. Sample distribution. In all groups 10 units $(n=10)$ were used.

\begin{tabular}{|c|c|c|c|}
\hline Group & Type of Bracket & Type of Ligature & Wire Diameter \\
\hline 01 & Clarity $^{\mathrm{TM}} \mathrm{SL}$ & --- & $0.018 "$ \\
\hline 02 & Clarity $^{\mathrm{TM}} \mathrm{SL}$ & --- & $0.017 " \times 0.025 "$ \\
\hline 03 & Damon $3 \AA$ & --- & $0.018 ”$ \\
\hline 04 & Damon $3 \circledast$ & --- & $0.017 " \times 0.025 "$ \\
\hline 05 & In-Ovation $C R$ & -- & $0.018 "$ \\
\hline 06 & In-Ovation $C \otimes$ & --- & $0.017 " \times 0.025 "$ \\
\hline 07 & Radiance $®$ & SOni-tie $®$ & $0.018 ”$ \\
\hline 08 & Radiance $®$ & Sani-tie $®$ & $0.017 " \times 0.025 "$ \\
\hline 09 & Radiance $®$ & Slide $\AA$ & $0.018 ”$ \\
\hline 10 & Radiance $®$ & Slide $\circledast$ & $0.017 " \times 0.025 "$ \\
\hline
\end{tabular}

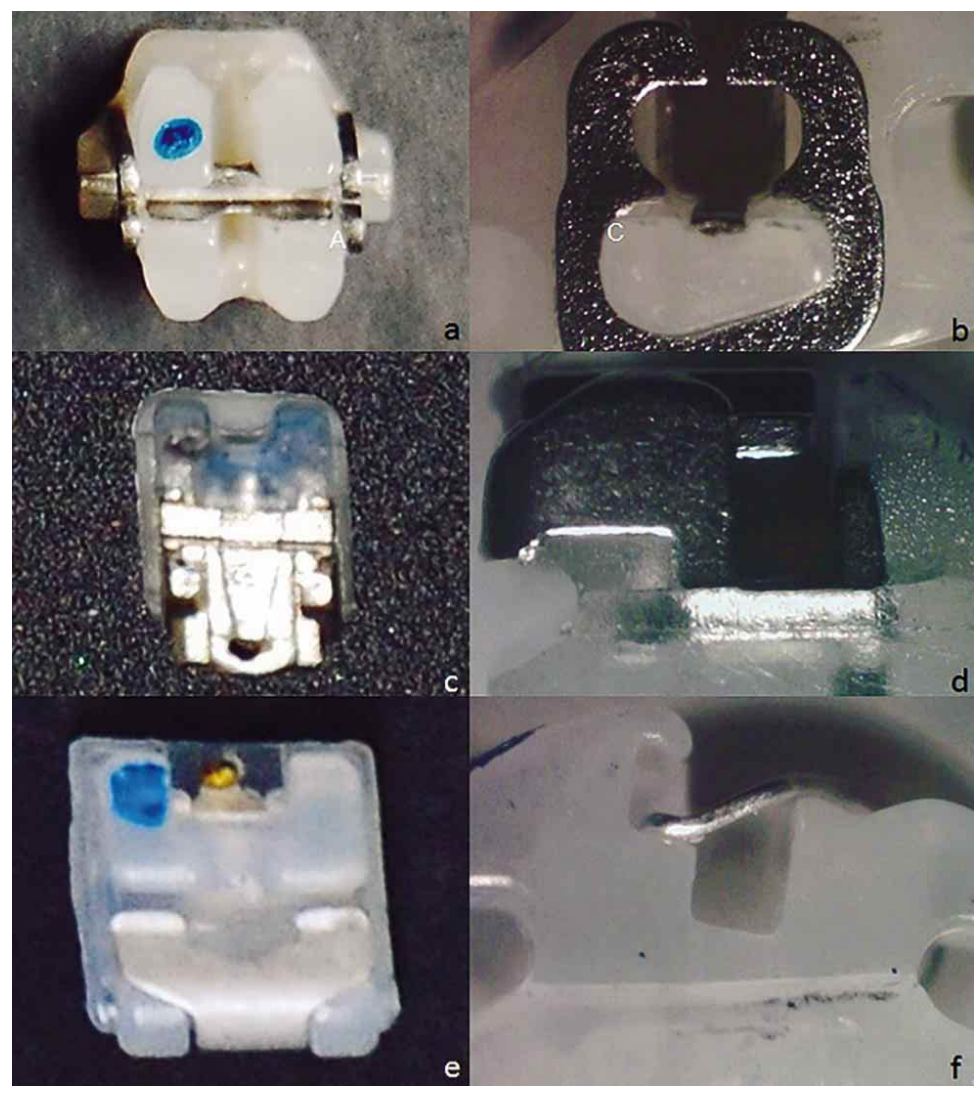

Fig. 1. Self-ligating brackets tested: Clarity ${ }^{\mathrm{TM}} \mathrm{SL}$ front view $(A)$ and side view (B); Damon $3 \circledR$ front view $(C)$ and side view $(D)$; In-Ovation $C \circledR$ front view $(E)$ and side view $(F)$.

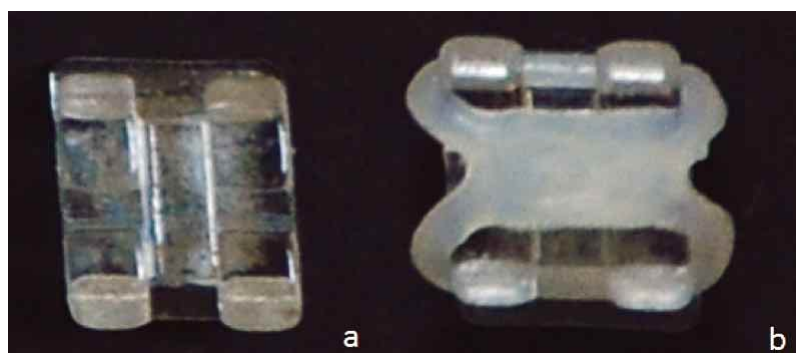

Fig. 2. Monocrystalline ceramic bracket Radiance ${ }^{\circledR}(A)$; Way of insertion of Slide ${ }^{\circledR}$ ligatura (B).
For the statistical analysis of the results obtained the software BioEstat (Belém, Brazil) was used. The median of the 5 consecutive tests performed in each test group was calculated. The studied variable (frictional force) is of a cardinal nature with normal distribution (normality verified by the D'Agostino test).

The existence of difference in frictional force among the groups in which rectangular wire was used and among the groups in which round wire was used was evaluated by the one-way ANOVA test, followed by the Bonferroni post hoc test with a level of significance adjusted to $0.5 \%$ (alpha value adjusted to 0.005).

The existence of difference in frictional resistance among the groups with the same bracket and different wires was evaluated by the Student's-t test, with a level of significance of $5 \%$ (alpha value of 0.05).

\section{RESULTS}

The control group with the conventional esthetic bracket presented the highest frictional force. The conventional esthetic brackets associated with low friction Slide $₫$ ligatures presented the lowest levels of frictional resistance, when compared with the same brackets associated with conventional elastic ligatures (Table II, Figs. 3 and 4). 
In the groups in which the round cross section wire was used, the self-ligating brackets presented no statistically significant difference among them with regard to the frictional force levels. This same result was observed when the self-ligating brackets were compared with the conventional esthetic bracket associated with the low friction ligature (Table II, Fig. 4).

In the groups in which the rectangular cross section wire was used, among the self-ligating brackets, In-Ovation $C \circledR$ exhibited the highest frictional force. Radiance $®$

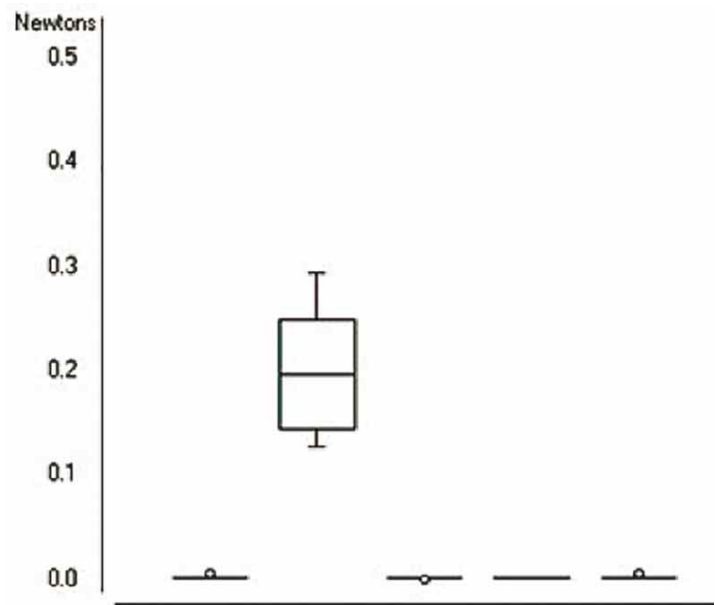

Fig. 3. Mean, standard deviation, minimum value and maximum value of frictional resistance in the 5 groups of brackets evaluated where: 1. Radiance+Slide/ round wire; 2 . Radiance + Conventional/round wire; 3. In-Ovation/round wire; 4. Damon/round wire and 5. Clarity/round wire. associated with the Slide $₫$ ligature, Damon $3 \AA$ and Clarity $^{\mathrm{TM}}$ SL exhibited similar results (Table II, Fig. 4).

To evaluate the influence of wire caliber on the static friction, a paired comparison was made with the Student's-t test, at a level of significance of $5 \%$ (alpha value of 0.05 ). The results showed that there was statistically significant difference $(p<0.05)$ for the tested brackets, except for the sample of Damon $3 \circledR$, Clarity ${ }^{\mathrm{TM}}$ SL and Radiance $®$ associated with the Slide $₫$ ligature $(p>0.05)$.

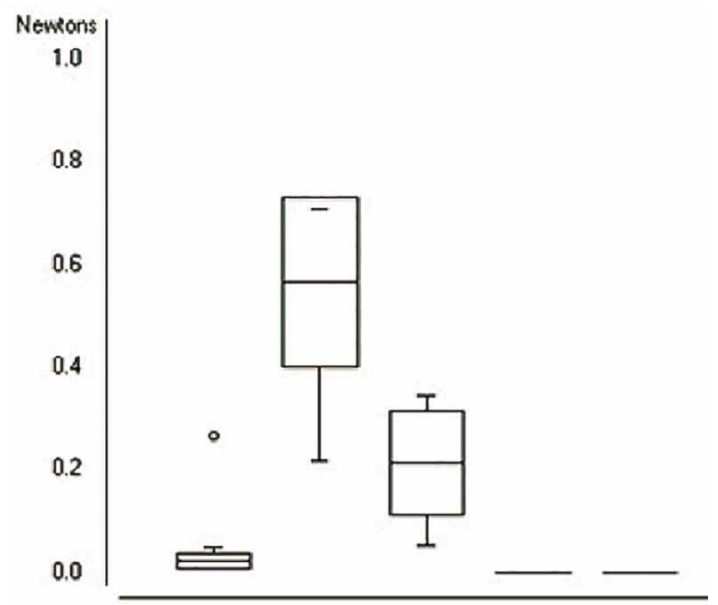

Fig. 4. Mean, standard deviation, minimum value and maximum value of frictional resistance in the 5 groups evaluated where: 1 . Radiance+Slide/rectangular wire; 2. Radiance+Conventional/rectangular wire; 3 . InOvation/rectangular wire; 4. Damon/rectangular wire and 5. Clarity/rectangular wire.

Table II. Mean and standard deviation of frictional resistance in the 10 groups evaluated.

\begin{tabular}{lllll}
\hline Type of Bracket/ Ligature & Mean & \multicolumn{3}{c}{ Wire caliber } \\
\cline { 3 - 5 } & & 0.018 " SS & $0.017 " \times 0.025 "$ SS \\
\cline { 3 - 5 } & & \multicolumn{1}{c}{ SD } & Mean & SD \\
\hline Radiance + Slide & 0.0014 & 0.0013 & 0.0455 & 0.0748 \\
Radiance + & 0.1967 & 0.053 & 0.5665 & 0.1649 \\
In-Ovation & 0.0009 & 0.0003 & 0.2142 & 0.1 \\
Damon & 0.001 & 0.0 & 0.001 & 0.0 \\
Clarity & 0.0014 & 0.0013 & 0.001 & 0.0 \\
\hline
\end{tabular}

p-value obtained by the one way ANOVA test, followed by the Bonferroni post hoc test with alpha value adjusted to 0.005 .

\section{DISCUSSION}

In the present study, the authors' proposal was to evaluate in vitro the frictional resistance force of different esthetic self-ligating brackets and a conventional esthetic bracket associated with an elastic ligature with a low frictional level and conventional elastic ligatures. The results found demonstrated that the esthetic self-ligating brackets tested exhibited similar levels of frictional force when used with 0.018 " round cross sectional stainless steel wire, with values close to or equal to zero. As all the brackets were bonded in a standardized manner with the stainless steel device, the prescription of angulation was thus eliminated. Therefore, this result could be 
related to the angulation of 0 ? between the wire and the channel walls, in addition to the fact that the round stainless steel wire has a smaller diameter in relation to the bracket slot dimension. Smaller diameter wires results in less filling of the bracket channel, and consequently a smaller area of contact with it (Thorstenson \& Kusy).

When the bracket In-Ovation $C \circledR$ was tested with a rectangular cross section wire of 0.017 " $\times 0.025$ ", it exhibited higher levels of frictional force when compared with the Damon $3 \circledR$ and Clarity ${ }^{\mathrm{TM}} \mathrm{SL}$ brackets. This result may be related to the active channel closing system, in the case of In-Ovation $C \circledR$, as opposed to the latter two, which are considered passive self-ligating brackets. In this active system, the passiveness of the self-ligating brackets is determined by the caliber of the wire, because the pressure of the channel clip against the wire is directly related to the diameter of the orthodontic wire used (Rinchuse \& Miles). Thorstenson \& Kusy compared passive and active self-ligating brackets and found results similar to those of the present study. According to these authors, rectangular wires exhibited a higher level of frictional force with active self-ligating brackets. On the other hand, wires of smaller diameter showed no statistically significant differences for the levels of friction in the different groups tested.

In spite of the higher levels of frictional resistance exhibited by In-Ovation $C \circledR$, its active closing system may, at certain stages of orthodontic treatment, represent a differential of this type of bracket, such as when there is a need for the expression of torques.

The results of this study demonstrated that the esthetic self-ligating brackets had lower frictional levels when compared with the conventional esthetic accessories. When Voudouris et al. (2010), conducted a study in which they evaluated esthetic self-ligating brackets, they observed that these presented low frictional levels, which were lower than the levels presented by metal and conventional self-ligating brackets.

The Slide $®$ elastic demonstrated lower frictional force when compared with the conventional elastic. This result may be associated with the capacity of low friction ligatures to play a role similar to that of the self-ligating bracket-closing clip, transforming the channel of the bracket into a structure similar to a tube. When compared with the self-ligating brackets the low friction system evaluated demonstrated similar frictional levels when the wire with the round cross section was used. Moreover, this system presented a similar performance to that of the Damon $3 \circledR$ and Clarity ${ }^{\mathrm{TM}} \mathrm{SL}$ brackets with regard to the frictional level when tested with 0.017 " $\times 0.025$ " wire, and lower values when compared with those of InOvation $C \circledR$. These results are in agreement with those found by Franchi et al. (2008), according to these authors, the low frictional ligatures produced levels of friction similar to those of self-ligating brackets and lower than those of traditional ligatures.

According to the results of this study the Slide $®$ elastic was shown to be a feasible alternative to the use of self-ligating brackets. This type of ligature is capable of transforming conventional brackets into low friction systems, in addition to the advantage of being able to be used in specific groups of teeth, in which low levels of friction are desired, thereby being more versatile than self-ligating brackets.

\section{CONCLUSION}

All the esthetic self-ligating brackets tested in this study demonstrated lower levels of frictional resistance when compared with conventional esthetic brackets associated with conventional elastic ligatures, irrespective of the cross section of the wire used.

In rectangular wires, the self-ligating brackets with active channel closing system presented a higher frictional force than the passive self-ligating brackets.

The conventional esthetic brackets associated with low friction ligatures presented lower frictional resistance than the conventional esthetic brackets with conventional elastic ligatures.

AMARAL, M. R. D.; NETO, P. S.; PITHON, M. M. \& OLIVEIRA, D. D. Evaluación in vitro de la resistencia friccional en brackets de autoligado estéticos y convencionales. Int. J. Odontostomat., 8(2):261-266, 2014.

RESUMEN: El objetivo fue evaluar la resistencia a la fricción producida en de brackets de autoligado estéticos y convencionales durante la simulación mecánica de deslizamiento ortodóncico. Se utilizaron cuatro tipos diferentes de soportes: 3 de tipo autoligado de diferentes marcas (Clarity ${ }^{\mathrm{TM}}$ SL, 3M Unitek; Damon $3 \AA$, Ormco Corporation; In-Ovation $C \circledR$, GAC International), además de brackets estéticos convencionales (Radiance $\AA$, American Orthodontics) asociado con ligaduras elásticas convencionales (Sani-tie $®$, GAC International) y ligaduras de baja fricción (Slide $\AA$, Leone). Para simular la mecánica de deslizamiento, se utilizaron alambres de acero 
inoxidable con un espesor de 0,018" y 0,017"x0.025" (GAC Internacional). Cinco grupos $(\mathrm{n}=10)$ fueron sometidos a cinco pruebas mecánicas consecutivas en una máquina de prueba universal modelo Emic DL ® 500. Los resultados mostraron niveles bajos de fricción en todos brackets de autoligado probados y con el uso de alambre de $0.018 "(p<0,05)$. Sin embargo, con alambe de 0,017x0,025", los grupos Damon 3, Clarity SL y Slide $®$ mostraron menores fuerzas de fricción en comparación con In-Ovation C ( $p>0,05)$. Por otra parte, los brackets estéticos convencionales asociados con ligaduras convencionales resultaron tener una mayor resistencia a la fricción con ambos alambres probados $(p>0,05)$. Todos los brackets de autoligado presentan niveles de fricción más bajo que los accesorios convencionales. El brackets activo de autoligado InOvation C, demostró un mayor grado de fuerza friccional cuando se asocia con alambre rectangular. La ligadura Slide $₫$ puede ser una alternativa al uso de brackets de autoligado.

PALABRAS CLAVE: fricción, resistencia a la tracción, brackets ortodóncico.

\section{REFERENCES}

Bazakidou, E.; Nanda, R. S.; Duncanson, M. G. Jr. \& Sinha, P. Evaluation of frictional resistance in esthetic brackets. Am. J. Orthod. Dentofacial Orthop., 112(2):138-44, 1997.

Fernandes, D. J.; Almeida, R. C. C.; Quintão, C. C. A.; Elias, C. N. \& Miguel, J. A. M. A estética no sistema de braquetes autoligáveis. R. Dent. Press Ortodon. Ortop. Facial, 13(3):97103, 2008

Fidalgo, T. K.; Pithon, M. M.; Maciel, J. V. \& Bolognese, A. M. Friction between different wire bracket combinations in artificial saliva--an in vitro evaluation. J. Appl. Oral Sci., 19(1):5762, 2011.

Franchi, L.; Baccetti, T.; Camporesi, M. \& Barbato, E. Forces released during sliding mechanics with passive self-ligating brackets or nonconventional elastomeric ligatures. Am. J. Orthod. Dentofacial Orthop., 133(1):87-90, 2008.

Fry, R. Self-ligating brackets. J. Clin. Orthod., 45(11):615-6, 2011.

Hain, M.; Dhopatkar, A. \& Rock, P. The effect of ligation method on friction in sliding mechanics. Am. J. Orthod. Dentofacial Orthop., 123(4):416-22, 2003.

Harradine, N. W. Self-ligating brackets and treatment efficiency. Clin. Orthod. Res., 4(4):220-7, 2001.

Huang, T. H.; Luk, H. S.; Hsu, Y. C. \& Kao, C. T. An in vitro comparison of the frictional forces between archwires and self-ligating brackets of passive and active types. Eur. J. Orthod., 34(5):625-32, 2012.

Kaklamanos, E. G. \& Athanasiou, A. E. Systematic review of self-ligating brackets. Am. J. Orthod. Dentofacial Orthop., 139(2):145-6; 2011.
Kao, C. T.; Guo, J. U. \& Huang, T. H. Comparison of friction force between corroded and noncorroded titanium nitride plating of metal brackets. Am. J. Orthod. Dentofacial Orthop., 139(5):594-600, 2011.

Pliska, B. T.; Beyer, J. P. \& Larson, B. E. A comparison of resistance to sliding of self-ligating brackets under an increasing applied moment. Angle Orthod., 81(5):794-9, 2011.

Regis, S. Jr.; Soares, P.; Camargo, E.S.; Guariza Filho, O.; Tanaka, O. \& Maruo, H. Biodegradation of orthodontic metallic brackets and associated implications for friction. Am. J. Orthod. Dentofacial Orthop., 140(4):501-9, 2011.

Ribeiro, A. A.; Mattos, C. T.; Ruellas, A. C.; Araújo, M. T. \& Elias, C. N. In vivo comparison of the friction forces in new and used brackets. Orthodontics (Chic.), 13(1):e44-50, 2012.

Rinchuse, D. J. \& Miles, P. G. Self-ligating brackets: present and future. Am. J. Orthod. Dentofacial Orthop., 132(2):216-22, 2007.

Shivapuja, P. K. \& Berger, J. A comparative study of conventional ligation and self-ligation bracket systems. Am. J. Orthod. Dentofacial Orthop., 106(5):472-80, 1994.

Tecco, S.; Marzo, G.; Di Bisceglie, B.; Crincoli, V.; Tetè, S. \& Festa, F. Does the design of self-ligating brackets show different behavior in terms of friction? Orthodontics (Chic.), 12(4):330-9, 2011

Thorstenson, G. A. \& Kusy, R. P. Comparison of resistance to sliding between different self-ligating brackets with secondorder angulation in the dry and saliva states. Am. J. Orthod. Dentofacial Orthop., 121(5):472-82, 2002.

Voudouris, J. C.; Schismenos, C.; Lackovic, K. \& Kuftinec, M. M. Self-ligation esthetic brackets with low frictional resistance. Angle Orthod., 80(1):188-94, 2010.

Yeh, C. L.; Kusnoto, B.; Viana, G.; Evans, C. A. \& Drummond, J. $\mathrm{L}$. In-vitro evaluation of frictional resistance between brackets with passive-ligation designs. Am. J. Orthod. Dentofacial Orthop., 131(6):704.e11-22, 2007.

Correspondence to:

Dauro Douglas Oliveira

Pontifícia Universidade Católica de Minas Gerais

Mestrado em Odontologia

Av. Dom José Gaspar

500 Prédio 46 - Sala 106

CEP 30535-610

Belo Horizonte - MG

Received: 07-01-2014

BRAZIL

Accepted: 30-05-2014

Email: dauro.bhe@gmail.com 